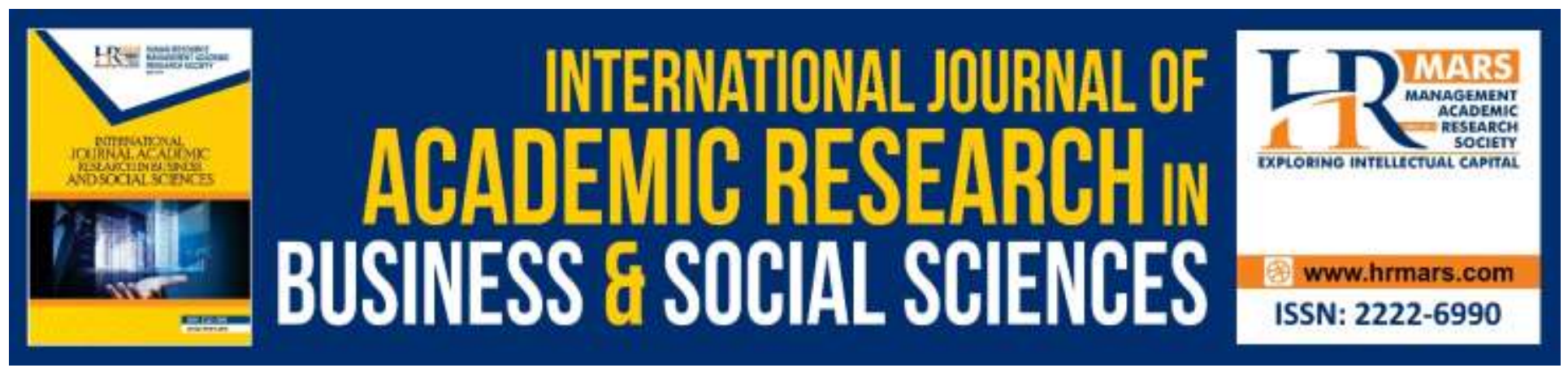

\title{
The Role of Self-Efficacy on Accounting Near-Graduate Students' Employment Outcomes
}

\author{
Lioubov Satchakova, Alex Taube
}

To Link this Article: http://dx.doi.org/10.6007/IJARBSS/v10-i2/7012

DOI:10.6007/IJARBSS/v10-i2/7012

Received: 19 January 2020, Revised: 03 February 2020, Accepted: 14 February 2020

Published Online: 29 February 2020

In-Text Citation: (Satchakova \& Taube, 2020)

To Cite this Article: Satchakova, L., \& Taube, A. (2020). The Role of Self-Efficacy on Accounting Near-Graduate Students' Employment Outcomes. International Journal of Academic Research in Business and Social Sciences, 10(2), 814-837.

\section{Copyright: (C) 2020 The Author(s)}

Published by Human Resource Management Academic Research Society (www.hrmars.com)

This article is published under the Creative Commons Attribution (CC BY 4.0) license. Anyone may reproduce, distribute, translate and create derivative works of this article (for both commercial and non-commercial purposes), subject to full attribution to the original publication and authors. The full terms of this license may be seen

at: http://creativecommons.org/licences/by/4.0/legalcode

\section{Vol. 10, No. 2, 2020, Pg. 814 - 837}

Full Terms \& Conditions of access and use can be found at http://hrmars.com/index.php/pages/detail/publication-ethics 


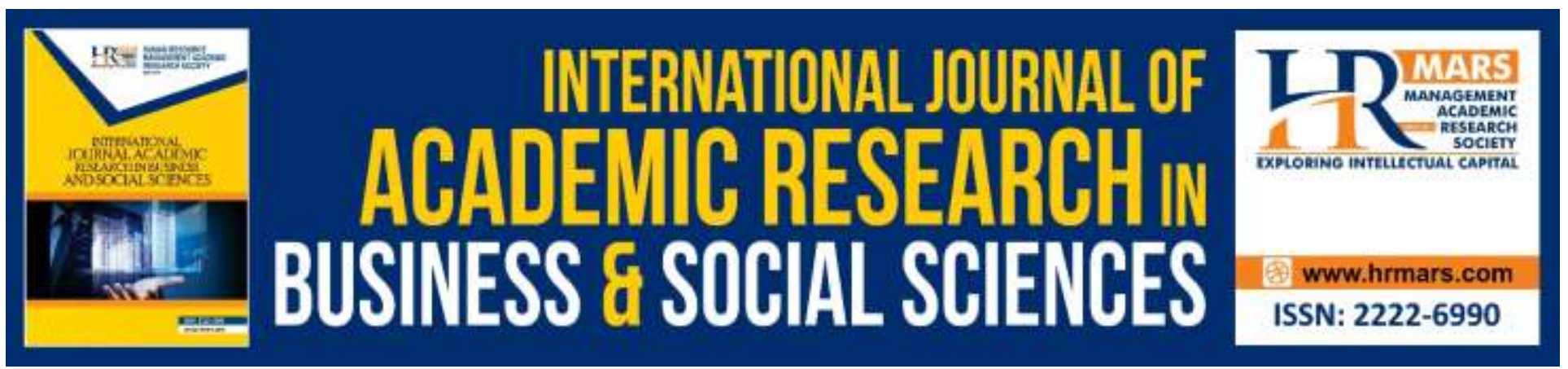

\title{
The Role of Self-Efficacy on Accounting Near- Graduate Students' Employment Outcomes
}

\author{
Dr. Lioubov Satchakova, Dr. Alex Taube \\ Swinburne University of Technology, Melbourne, Australia \\ Email: ataube@swin.edu.au
}

\begin{abstract}
Advances in artificial intelligences and robotics have modernized the business environment of the 21st century. It is not enough for graduates to have only the occupation-specific knowledge and transferrable kills for graduates to meet the needs of labour markets. They are also expected to have a number of personal attributes including self-awareness, self-confidence, independence, emotional intelligence, flexibility and adaptability, creativity and initiative, willingness to be lifelong learner. The present research analyses the association between the three self-efficacy factors of the general selfefficacy scale (GSES): initiative, effort and persistence on accounting near-graduate employment outcomes. The study sample consisted of 337 near-graduate accounting students from Victoria University and Swinburne University of Technology, Melbourne, Australia. The research employed logistic regression, as well as Lasso and R-glmulti statistical techniques, to examine the main research questions. In addition, Mann-Whitney $U$ tests and Pearson chi-square tests were conducted to examine the association between accounting students' individual characteristics and the three factors of GSES.
\end{abstract}

Keywords: Self-Efficacy Factors, Employability, Personal Attributes, Near-Graduates.

Introduction

The focus for educators and curriculum developers is finding ways to maximize results for all students to ensure their employability. Employability skills become a very important issue at the national, regional, and international labour market. Communication skills, problem-solving and decisionmaking skills, teamwork skills, and of course self-efficacy are the attributes of employability skills with highest importance level.

A growing number of repetitive tasks are being delegated to robots, leaving accountants with more time to look for value-added opportunities. The new demands need a new generation of accountants that are more than just pure accountants. They are also expected to have a multitude of skills to enable them to become management consultants, auditors, financial analysts, tax experts, business system consultants, actuary, bookkeeping expert and many more. 
INTERNATIONAL JOURNAL OF ACADEMIC RESEARCH IN BUSINESS AND SOCIAL SCIENCES Vol. 10, No. 2, Feb, 2020, E-ISSN: 2222-6990 @ 2020 HRMARS

Famous phrase: "They can because they think they can", wrote by Virgil's more than two thousand years ago, still highlights tailoring parts of the curriculum, in order to improve student self-efficacy. Self-efficacy refers to people's judgements of their capabilities to organise and execute courses of action required to attend designated types of performances (Bandura, 1986, p. 391). Self-efficacy theory holds a view that one's beliefs, thoughts and feelings about individual capabilities influence the self-control of one's actions (Bandura, 1977, 1986), leading to the desired outcome. For the present research, this equates to securing employment.

According to Tymon (2011), Bandura (1997), and Smith and Betz (2000), students with a proactive personality develop better capabilities and are more successful in terms of employment outcomes. Such capabilities comply with the self-efficacy concept (Bandura, 1977, 1982, 1997), which assumes "beliefs in one's capabilities to mobilise the motivation, cognitive resources, and courses of action needed to meet given situation demands" (Wood \& Bandura, 1989, p. 408).

There are two types of self-efficacy: general and specific. General self-efficacy (GSE) is based on traitlike constructs predetermined by personal characteristics; specific self-efficacy (SSE) assumes statelike qualities that are influenced by particular circumstances in specific situations. SSE is very task specific, while the focus of GSE is on intention and outcome expectations (Chen et al. 2001). Since the present research is focused on employment outcomes, GSE is adopted for this study, specifically, the three factor GSES construct that incorporates initiative, effort and persistence.

As indicated earlier, the three factors of the GSES (initiative, effort and persistence) are viewed as important contributing factors for achieving desired outcomes (Bosscher \& Smit, 1998; Sherer et al. 1982). In the context of the present research, these desired outcomes are associated with the employment outcomes of accounting near-graduate students. Despite the importance of these GSES factors to achieving desired outcomes, analysis of initiative, effort and persistence has not been pursued in the accounting education area - either generally or with respect to employment outcomes of near-graduates.

The three-factor construct allows for the impact of each individual factor to be analysed independently of each other. Such an approach enables a more in-depth exploration of the potential association between self-efficacy and accounting near-graduates' employment outcomes.

To examine empirically the association between variables related to the employment outcomes of accounting near-graduates, the data collection via questionnaire obtained students' perceptions of their self-efficacy using GSES measurements (Sherer et al. 1982; Bosscher \& Smit, 1998).

The study sample included 337 near-graduate accounting students from Victoria University (VU) and Swinburne University of Technology, both based in Melbourne, Australia. The sample data was tested using a principal component analysis (PCA), and a Mann-Whitney $U$ test and Pearson chisquare for tests of association (RQ1), as well as the logistic regression models, and the Lasso and the R-glmulti statistical tools (RQ2 and RQ3). The latter two statistical techniques were designed to provide rigour and robustness to the findings of the logistic regression model (Field 2009). For example, the Lasso includes a regression analysis method that performs both variable selection and regularisation in order to enhance the prediction accuracy and interpretability of the statistical model it produces (Tibshirani, 1996).

Many studies have revealed the dependency between employment and GSE. Guan et al. (2013) applied a self-efficacy theory in studying Chinese graduates' career adaptability and job search 
INTERNATIONAL JOURNAL OF ACADEMIC RESEARCH IN BUSINESS AND SOCIAL SCIENCES

Vol. 10, No. 2, Feb, 2020, E-ISSN: 2222-6990 @ 2020 HRMARS

outcomes, emphasising a strong positive correlation between perceived self-efficacy and job search progress.

There is also a positive association between self-efficacy and employment outcomes, as outlined by Sherer et al. (1982), Tymon (2011), Demagalhaes et al. (2011), Jackson (2013), Freudenberg et al. (2010b), Rothwell et al. (2008) and Smith and Bentz (2000). Bandura (1997) also stated that an individual's belief that they will gain employment is associated with their self-efficacy and belief in their ability to achieve. Knight and Yorke (2004) also argued that self-efficacy beliefs affect peoples' employment outcomes.

Our study results indicate that two out of the three GSES factors (specifically, initiative and persistence) showed a significant relationship with the employment outcomes of near-graduate accounting students.

\section{Conceptual Framework}

General Self-Efficacy (GSE) factors represented by persistence, initiative and effort were included in the conceptual framework due to their influence on attainment of desired outcomes. In addition, the environmental factors, which assume different influences of specific environments within which an individual is situated, were also included via student experiences from WIL participation.

The conceptual framework developed for this study was underpinned by Social Cognitive Theory (SCT). The SCT incorporates three interacting components: personal factors, environmental factors and the behaviour of people. According to SCT, the behaviour of people is influenced by their individual characteristics. Therefore, the conceptual framework developed for this research included the individual characteristics of students (i.e., age, gender, language, residency and study mode), to be analysed to address the research problem.

Thus, the self-efficacy construct is based on SCT (Bandura, 1977, 1982, 1997; Sherer et al. 1982; Bosscher \& Smit, 1998), while student characteristics and WIL are based on established prior literature (Tymon, 2011; Smith, 2012; Jackson, 2013, 2014; Freudenberg et al. 2010a). In addition, the twelve research hypotheses developed for this study align with the positivist paradigm applied in this research.

As a result of the identified main research problem discussed above, three specific research questions arose:

RQ1: Is there any association between accounting near-graduate students' individual characteristics and the self-efficacy components of the GSES?

RQ2: What are the factors that influence the employment outcomes of accounting neargraduate students?

RQ3: Do self-efficacy factors influence accounting near-graduate students' participation in WIL?

Hence, the objectives pursued to answer the research questions are:

- To examine the relationship between the individual characteristics and self-efficacy of accounting near-graduates.

To achieve this, the present study analysed a 12-item GSE construct via a principal component factor analysis to confirm the three-factor construct: initiative, effort and persistence (Bosscher \& Smit, 1998; Sherer et al. 1982). The self-efficacy construct was then tested against the grouping of 
INTERNATIONAL JOURNAL OF ACADEMIC RESEARCH IN BUSINESS AND SOCIAL SCIENCES Vol. 10, No. 2, Feb, 2020, E-ISSN: 2222-6990 @ 2020 HRMARS

students based on the following categorical variables: (i) gender, (ii) residency, (iii) language, (iv) age and $(v)$ study mode. The selection of these variables is justified later in the thesis.

- To estimate the relationship between employment and the following independent variables: accounting students self-efficacy factors (initiative, effort and persistence) as well as gender, residency, language, age, study mode and WIL participation.

To achieve this, the present research examined the above variables via the application of statistical techniques comprising a logistic regression model, as well as Lasso ${ }^{1}$ and R-glmulti analysis.

- To estimate the association between WIL participation and accounting students' self-efficacy factors (initiative, effort and persistence) to identify whether their self-efficacy influences their involvement in WIL.

To achieve this, the present research examined the three self-efficacy factors and WIL participation via a logistic regression model for WIL, along with Lasso and R-glmulti analysis.

Thus, with respect to achieving these objectives, the present research adopted a quantitative approach in investigating the association between the aforementioned variables. Figure 1 shows the range of variables and their association between individual characteristics and self-efficacy in a threefactor construct.

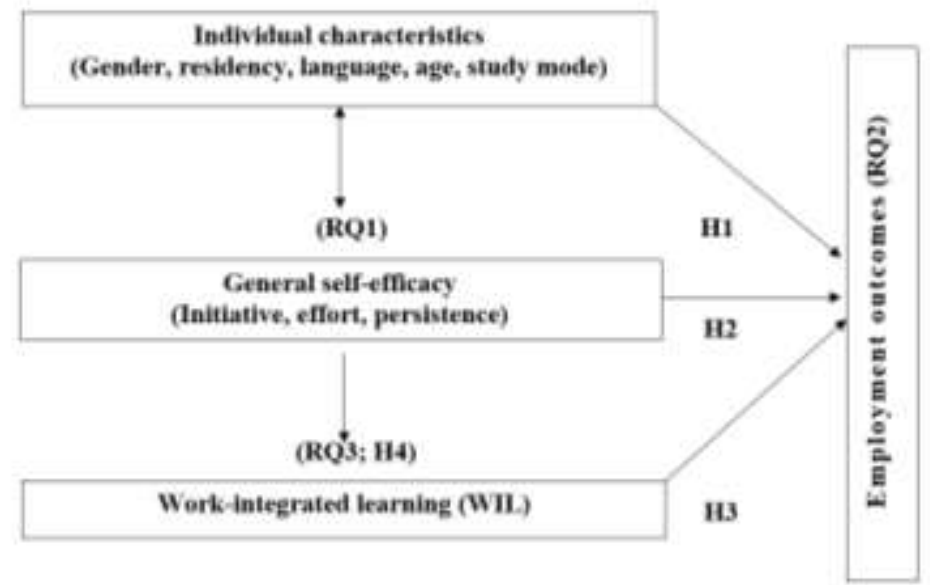

Figure 1. Research method employed in the present study.

The conceptual framework was designed to examine association between individual characteristics and self-efficacy; therefore, a research method was adopted to accommodate this.

The present research employed a positivist paradigm. Given the outlined research objectives, a quantitative approach was employed via the use of a questionnaire as the research instrument for collecting data. The statistical methods selected for addressing the research questions are as follows: a Principal Component Analysis (PCA) method to validate a factor analyses of GSES, and MannWhitney U-test and Pearson chi-square for tests of association between variables for RQ1; and to develop two separate logistic regression models for RQ2 and RQ3 that both have binary dependent variables. The methods selected are both valid and justifiable for this type of study.

\footnotetext{
${ }^{1}$ Lasso refers to the least absolute shrinkage and selection operator regression method.
} 
INTERNATIONAL JOURNAL OF ACADEMIC RESEARCH IN BUSINESS AND SOCIAL SCIENCES Vol. 10, No. 2, Feb, 2020, E-ISSN: 2222-6990 @ 2020 HRMARS

The usefulness of business studies depends, in part, upon the appropriateness and accuracy of the methods adopted (Scandura \& Williams, 2000). This is because design choices regarding instrumentation, data analysis, and construct validation influence the soundness of the conclusions drawn from the findings (Sackett \& Larson, 1990). This outlines the approach utilised in this study that were justified above: (i) factor analysis using a PCA method; (ii) Mann-Whitney U-test and Pearson chi-square for tests of association; and (iii) logistic regression using Statistical Package for the Social Sciences (SPSS), and Lasso and R-gImulti techniques.

\section{Factor Analysis}

Factor analysis is a statistical method of analysing research data, which was introduced and conceptualised by Spearman (1904). The purpose of factor analysis is to discover simple patterns in the relationships among the variables. More specifically, the factor analysis is carried out by examining the pattern of correlations between the observed measures (or variables). Measures that have higher correlations (either positive or negative) are likely to be influenced by similar factors, whereas those that are not correlated are likely to be influenced by different factors (DeCoster, 1998).

The factor analysis method was used in this study for the self-efficacy construct, comprising the 12item GSES (Bosscher \& Smit, 1998; Sherer et al. 1982). This method allowed the researcher to reduce the number of items into more manageable identified factors for subsequent inclusion in the logistic regression models for employment. Factor analysis is a powerful tool, which enables one to draw correlations between variables and is used for analysis techniques in constructing factor models (Thompson, 2004).

\section{Assumptions of Factor Analysis}

Sample Size

Factor analysis requires a reasonable sample size in order to be effective (Comrey \& Lee, 1992). Since this method of statistical analysis is based on correlations amongst the items, a good estimate of each pair-wise correlation is required. The literature provides typical guidelines for factor analysis sample size and a total sample size of $n>200$ is recommended (Collis \& Hussey, 2009). According to Comrey and Lee (1992), sample sizes for factor analysis can be viewed as follows: 50=very poor, 100=poor, 200=fair, 300=good, 500=very good, 1000+= excellent.

Level of measurement assumption

The level of measurement assumption requires all variables to be in the form of ratios, metric data or Likert data with several interval levels (Pallant, 2013). Dummy variables can also be used for specialised methods and these dummy variables can be part of metric variables to be used in factor analysis.

Normality-Q

Factor analysis is robust to assumptions of normality. If the variables are normally distributed, the solution of the analysis is enhanced (Field 2009). Thus, the normality of the self-efficacy variable (12item GSES) is tested using SPSS functions, such as histograms, Q-Q plots, detrended normal Q-Q plots and boxplots. 
INTERNATIONAL JOURNAL OF ACADEMIC RESEARCH IN BUSINESS AND SOCIAL SCIENCES

Vol. 10, No. 2, Feb, 2020, E-ISSN: 2222-6990 @ 2020 HRMARS

Linearity

Since factor analysis is based on correlations between variables, linear relations amongst the variables need to be tested (Pallant, 2013). This is typically undertaken via producing scatter plots and partial regression plots.

Outliers, multicollinearity and heteroscedasticity

Many researchers emphasise that factor analysis is sensitive to outliers (Phillips 2015; Field 2009; Pallant, 2013); therefore, testing is required. Since this study dealt with survey data, scatter plots for bivariate outliers and boxplots for the self-efficacy construct were employed to identify any potential outliers. With respect to multicollinearity, the VIF and tolerance (i.e., measure of the unique contribution of each variable to the model) were computed on Statistical Package for the Social Sciences (SPSS), while the scatter plot of residuals against regression standardised predicted values were also examined to test heteroscedasticity.

\section{Selecting the Type of Analysis}

Two different types of factor analysis are used in research: (i) Exploratory Factor Analysis (EFA); and (ii) Confirmatory Factor Analysis CFA (Thompson 2004). EFA attempts to find the nature of the constructs influencing a set of various responses, while CFA examines whether an identified set of constructs is influencing the responses in some predicted manner (DeCoster, 1998).

As DeCoster (1998) pointed out, regardless of the method selected, any factor analysis is based on the common factor model, as shown in Figure 2 below. In this model, the strength of the links between each factor and each measure can vary since a given factor can influence some measures more than other factors.

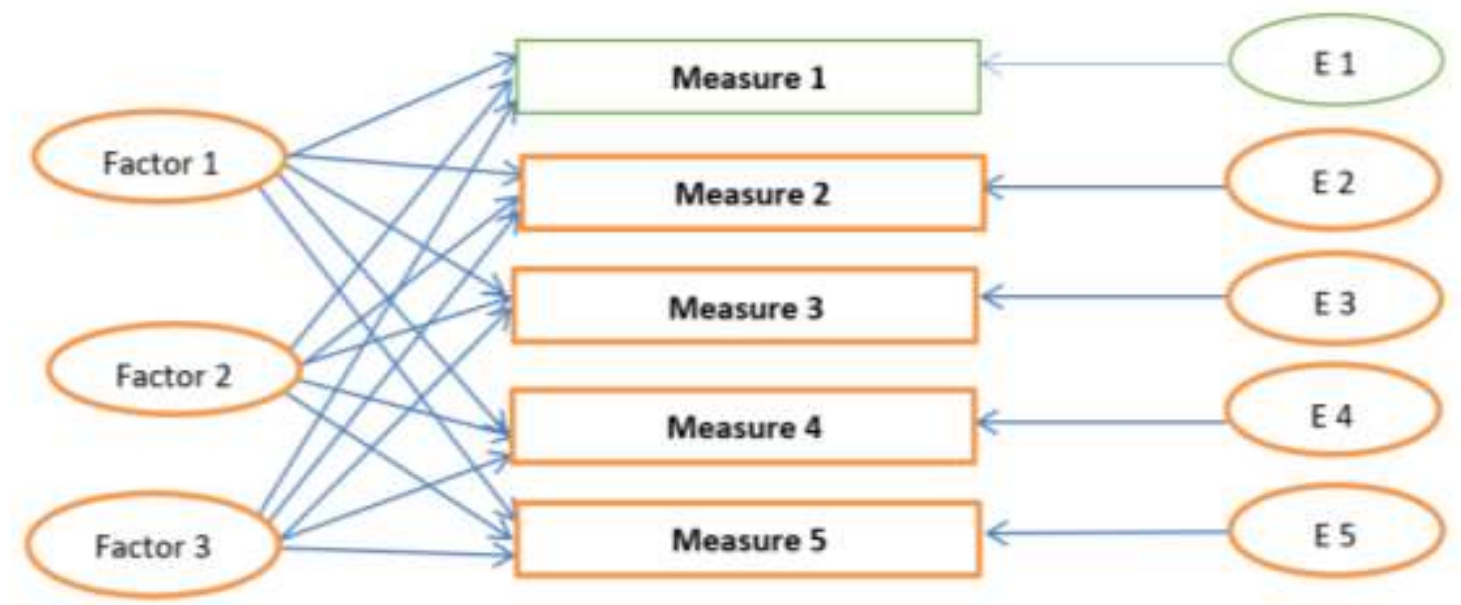

Figure 2: Common factor model. Adapted and modified from DeCoster (1998)

The above model shows that each observed response (measure one to measure five, or a five-point Likert Scale) is influenced by an underlying common factor (factor one to factor three). At the same time, each response is also partially influenced by underlying unique factors (E1 to E5 such as items/statements). However, despite their similarity via the common model, the two methods (EFA and CFA) contain some differences (Field, 2009). 
INTERNATIONAL JOURNAL OF ACADEMIC RESEARCH IN BUSINESS AND SOCIAL SCIENCES Vol. 10, No. 2, Feb, 2020, E-ISSN: 2222-6990 @ 2020 HRMARS

Specifically, EFA is used to identify the underlying relationships between measured variables (Thompson, 2004), to reveal the underlying structure of a relatively large number of variables (Field, 2009). The objective of EFA, therefore, is to identify factors based on analysed data. With EFA, the researcher is not required to have any specific hypotheses about how many factors or what variables these factors will include.

CFA, however, is predominantly driven by concepts or theory. It requires the number of factors, whether or not these factors are correlated, and which items or measures reflect which factors (Thompson, 2004). With CFA, the researcher is expected to have specific expectations regarding the number of factors; which variables reflect given factors; and whether the factors show dependency or are correlated. Therefore, CFA explicitly and directly tests the fit of factor models (Thompson, 2004).

Factor analysis is also used for data reduction by identifying the typical variables from a large set of variables. The purpose of data reduction via factor analysis is to retain the nature and character of the original variables but reduce the variable number for facilitation of the subsequent multivariate analysis. Therefore, the reduction of variables involves obtaining a relatively small number of components that can account for variability found in larger number of measures. This can be achieved by employing PCA (DeCoster, 1998; Field, 2009; Comrey \& Lee, 1992; Thompson, 2004; Pallant, 2013). The following figure shows the PCA model.

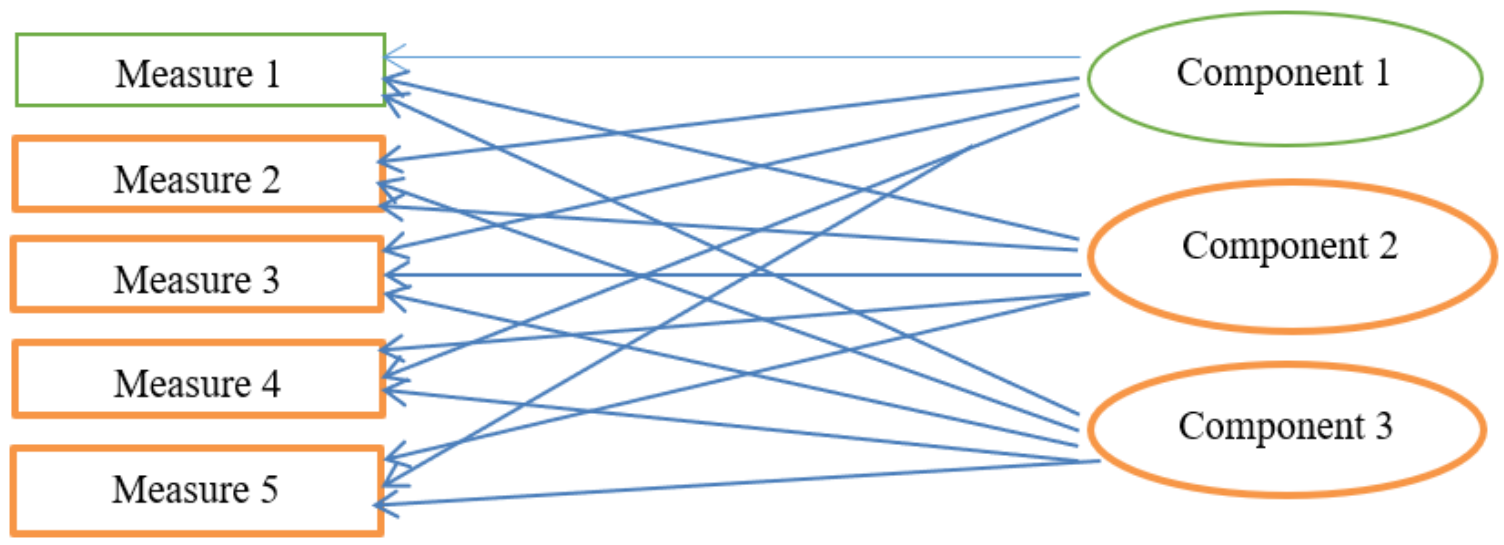

Figure 3: Principal component analyses model. Source: Adapted and modified from DeCoster (1998)

As shown above, the direction of the influence in PCA is reversed when compared to the common factor model. Unlike the common factor model, the PCA is not constructed on the assumption of underlying factors. Rather, the PCA model is based on the measured responses. Furthermore, it is defined simply as a linear relationship of measurements and therefore contains both the common and unique variance (DeCoster, 1998).

According to Hair et al. (2006), both models provide relatively identical results in common research settings ( $>30$ variables or $>0.6$ communality for most variables). Thus, a common factor model is used because there is a well-defined theoretical concept (Sherer et al. 1982; Bosscher \& Smit, 1998), and PCA can be employed specifically in order to reduce data. 
Thus, this study employed PCA for factor analysis of the self-efficacy construct. The use of a PCA as a type of CFA is supported by Field (2009) and has been used in prior studies (McDowall et al. 2015; Guadangnoli \& Velicer, 1988).

The determination of the number of factors is based on considerations of their eigenvalue, which indicates the importance of the factor and represents the amount of variation explained by a factor. An eigenvalue of 1 represents a substantial variation, therefore factors with eigenvalues of $>1.0$ are retained. Hinton (2004) suggested that only factors with eigenvalues greater than one should be retained, as they explain more variance than factors with eigenvalues of one or less.

To improve the interpretability of the factors, further analysis involves varimax and oblique rotation of the factors due to the un-rotated solutions of factor analysis that are often not sufficient for defining the results (DeCoster, 1998; Field, 2009). Therefore, preliminary results are further tested via rotation for improved interpretation of the data results by considering factor loadings.

In addition, factor loadings indicate the correlation of the item with the factor. It expresses how much a factor explains a variable in factor analysis. Factor loadings can range from -1 to 1 , where loadings close to -1 or 1 are an indication that the specific factor strongly affects the variable. Loadings close to zero indicate that a factor has very little effect on the variable (Coakes, 2013; Pallant, 2013)

Communality is the proportion of the variance of an item, explained by the common factors in a factor analysis. According the Hair et al. (2010), variables should have communalities of $>0.50$ to be retained in the factor analysis. The optimal structure is considered to exist when all of variables have high loading on only one factor.

\section{Examining Correlations amongst Factors}

Prior to employing factor analysis, the variables are required to be measured at the same experimental units. To check the suitability of the data for factor analysis, it is important to test the factorability of the correlation's matrix. This involves assessing the matrix for correlations over 0.3 (Field, 2009).

The anti-image matrix displays the negatives of the partial correlation coefficients; therefore, most of the off-diagonal elements should be small for a good factor model. Hence, anti-image correlation matrix diagonals over 0.50 need to be checked together with the Kaiser-Mayer-Olkin (KMO) measures of sampling adequacy. The KMO test examines the sampling adequacy and is typically required to be $>0.50$. Variables of value less than 0.50 are excluded from factor analysis one at a time; each time the smallest item is omitted (Field, 2009; Pallant, 2013). In addition, Bartlett's test of sphericity examines homogeneity of variance of the data. A significance level of $<0.05$ is considered statistically significant and indicates the existence of sufficient correlation among the variables to perform a PCA factor analysis.

Analyse internal reliability

Reliability of the degree of consistency between the 12 items of the GSES is measured via Cronbach's alpha. Cronbach alpha is defined as:

$$
\alpha=\frac{N \cdot \bar{c}}{\bar{v}+(N-1) \cdot \bar{c}}
$$

Where, $\alpha$ is the Cronbach alpha, $N$ is the number of items, $\bar{c}$ is average covariance between itempairs, and $\bar{v}$ is the average variance (Hosmer \& Lemeshow 2000). 
When assessing the Cronbach alpha, the study should give consideration to the specific attribute of this measure. That is, the Cronbach alpha is deemed to have a positive relationship with the number of items in the scale. The larger the number of the items in the scale, the higher the scale's reliability is expected to be, indicating a higher Cronbach alpha value.

The present study conducted a factor analysis on the 12-item self-efficacy construct. Specifically, a PCA analysis was used as a type of CFA (McDowall et al. 2015; Guadangnoli \& Velicer, 1988; Field, 2009) to reduce the number of items in accordance with a well-defined theoretical concept (Sherer et al. 1982; Bosscher \& Smit, 1998). Factor analysis was used to identify particular aspects of the selfefficacy construct in the sample data. In addition, tests of association include, but are not limited to, t-tests and one-way ANOVA for a study with a normal distribution of data, as well as a Mann-Whitney $\mathrm{U}$ test and Kruskal-Wallis test for a study with a non-normal distribution of data. Depending on the distribution of data, the appropriate tests of association will be employed to address RQ1 below: RQ1: Is there any association between accounting near-graduate students' individual characteristics and the self-efficacy components of the GSES? The study employed factor analysis and association tests to address RQ1. The following assumptions needed to be met for the data analyses in this study. Sample size

With respect to factor analysis, typical guidelines recommend sample size $n>200$ as a fair sample (Comrey \& Lee, 1992), with a minimum sample size of five cases per variable factor and an ideal sample of more than 20 cases per variable. The GSES includes 12 items, which would require at least 60 cases for a minimum sample size ( $n>5$ cases per variable factor) and 240 cases for an ideal sample size ( $\mathrm{n}>20$ cases per variable factor). The study's sample of 337 cases was therefore classified as 'good' based on the above guidelines.

\section{Diagnostic tests}

A number of diagnostic tests were performed. The results showed that the study data did not exhibit multicollinearity. Since factor analysis is based on correlations between the variables, linear relations amongst the items of the GSES needed to be tested.

In addition, the test for normality of data, outliers, and heteroscedasticity were performed. The results did not reveal any issues with data. 


\begin{tabular}{|c|c|c|c|c|c|c|c|c|}
\hline Self -efficacy item & $\stackrel{\frac{c}{\pi 0}}{\stackrel{\mathbb{d}}{\Sigma}}$ & $\frac{\frac{c}{\sigma 0}}{\frac{\pi}{0}}$ & 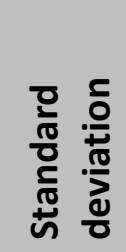 & 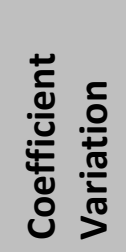 & $\frac{\check{y}}{\sum_{0}^{u}}$ & $\begin{array}{l}\frac{n}{n} \\
\stackrel{n}{\frac{1}{2}} \\
\underline{x}\end{array}$ & $\frac{\underline{\varepsilon}}{\underline{\underline{\varepsilon}}}$ & $\begin{array}{l}\frac{E}{3} \\
\stackrel{\underline{E}}{x} \\
\sum^{\pi}\end{array}$ \\
\hline $\begin{array}{l}\text { 1) If I make plans, I am } \\
\text { convinced I will succeed in } \\
\text { executing them }\end{array}$ & 4.26 & 4.0 & 0.688 & 0.162 & -1.274 & 3.413 & 1 & 5 \\
\hline $\begin{array}{l}\text { 2) If I have a failure the first } \\
\text { time, I bite into it until it is } \\
\text { going better }\end{array}$ & 4.27 & 4.0 & 0.726 & 0.170 & -1.268 & 2.457 & 2 & 5 \\
\hline $\begin{array}{l}\text { 3) If I absolutely want } \\
\text { something, it usually goes } \\
\text { wrong }(\mathrm{R})\end{array}$ & 3.51 & 4.0 & 1.008 & 0.287 & -1.056 & 0.191 & 1 & 5 \\
\hline $\begin{array}{l}\text { 4) If I have the impression } \\
\text { something new is } \\
\text { complicated, I do not start } \\
\text { it (R) }\end{array}$ & 3.56 & 4.0 & 1.003 & .282 & -0.872 & -0.307 & 1 & 5 \\
\hline $\begin{array}{l}\text { 5) Even with unpleasant } \\
\text { tasks I hold on until I am } \\
\text { finished }\end{array}$ & 4.05 & 4.0 & 0.966 & 0.236 & -1.371 & 2.881 & 1 & 5 \\
\hline $\begin{array}{l}\text { 6) I have difficulties solving } \\
\text { problems well in my life (R) }\end{array}$ & 3.58 & 4.0 & 1.086 & 0.303 & -0.820 & -0.391 & 1 & 5 \\
\hline $\begin{array}{l}\text { 7) If I have made a decision } \\
\text { to do something, I will do it }\end{array}$ & 4.28 & 4.0 & 0.715 & 0.167 & -1.303 & 3.015 & 1 & 5 \\
\hline $\begin{array}{l}\text { 8) If I start something new, } \\
\text { I soon have to have the } \\
\text { idea I'm on the right track, } \\
\text { otherwise I quit (R) }\end{array}$ & 2.98 & 3.0 & 1.234 & 0.414 & -0.042 & -1.360 & 1 & 5 \\
\hline $\begin{array}{l}\text { 9) Unexpected problems } \\
\text { make me quickly lose my } \\
\text { balance }(R)\end{array}$ & 3.28 & 4.0 & 1.141 & 0.348 & -0.503 & -1.106 & 1 & 5 \\
\hline $\begin{array}{l}\text { 10) If I make a mistake, I try } \\
\text { even harder }\end{array}$ & 4.10 & 4.0 & 0.804 & 0.196 & -1.157 & 1.508 & 2 & 5 \\
\hline $\begin{array}{l}\text { 11) I do not start learning } \\
\text { new things if I think they } \\
\text { are too difficult }(R)\end{array}$ & 3.75 & 4.0 & 1.059 & 0.282 & -1.084 & 0.426 & 1 & 5 \\
\hline 12) I doubt myself (R) & 3.42 & 4.0 & 1.263 & 0.369 & -0.464 & -1.060 & 1 & 5 \\
\hline
\end{tabular}

Table 1: Descriptive statistics of the 12-item GSES variable

Please note that the $(R)$ refers to an item that was reverse-coded prior to analysis in accordance with accepted practice. Table 1 shows that for the 12 -item GSES variable, the mean varied between 2.98 to 4.28. The minimum value was 1 ('strongly disagree') and maximum was 5 ('strongly agree') with 
INTERNATIONAL JOURNAL OF ACADEMIC RESEARCH IN BUSINESS AND SOCIAL SCIENCES Vol. 10, No. 2, Feb, 2020, E-ISSN: 2222-6990 @ 2020 HRMARS

3 being 'neutral'. The mean values in addition to median values were all above the neutral value of 3 , except for item 8, which was close to neutral (2.98). The values of skewness were between -1.371 and -0.042 , while kurtosis values ranged from -1.360 to 3.413. Four items of GSES demonstrated a kurtosis value above 2 (items 1, 2, 5 and 7 as shown in table above). Most of the 12 items in the GSES indicated normal univariate distribution, since their skewness and kurtosis were between the acceptable values and did not exhibit any issues (George \& Mallery 2010).

Further, Pearson correlations were employed on the 12-item GSES due to the parametric nature of this variable. The correlations within the 12 -item GSES revealed the strength and the direction of the relationships between them, as shown in the following table.

\begin{tabular}{|c|c|c|c|c|c|c|c|c|c|c|c|c|}
\hline & $\begin{array}{c}\text { Self-eff } \\
1\end{array}$ & $\begin{array}{c}\text { Self-eff } \\
2\end{array}$ & $\begin{array}{c}\text { Self-eff } \\
3\end{array}$ & $\begin{array}{c}\text { Self-eff } \\
4\end{array}$ & $\begin{array}{c}\text { Self-eff } \\
5\end{array}$ & $\begin{array}{c}\text { Self-eff } \\
6\end{array}$ & $\begin{array}{c}\text { Self-eff } \\
7\end{array}$ & $\begin{array}{c}\text { Self-eff } \\
8\end{array}$ & $\begin{array}{c}\text { Self-eff } \\
9\end{array}$ & $\begin{array}{c}\text { Self-eff } \\
10\end{array}$ & $\begin{array}{c}\text { Self-eff } \\
11\end{array}$ & $\begin{array}{c}\text { Self-eff } \\
12\end{array}$ \\
\hline Self-eff 1 & $\mathrm{x}$ & & & & & & & & & & & \\
\hline Self-eff 2 & $0.316^{* *}$ & $x$ & & & & & & & & & & \\
\hline Self-eff 3 & 0.095 & 0.096 & $x$ & & & & & & & & & \\
\hline Self-eff 4 & $0.140^{*}$ & $0.131^{*}$ & $0.254^{\text {*4 }}$ & $\mathrm{x}$ & & & & & & & & \\
\hline Self-eff 5 & $0.329 * *$ & $0.215^{*}$ & 0.071 & $0.124^{*}$ & $\mathrm{x}$ & & & & & & & \\
\hline Self-eff 6 & $0.129 *$ & 0.023 & $0.164^{* *}$ & $0.182^{* *}$ & 0.060 & $\mathrm{x}$ & & & & & & \\
\hline Self-eff 7 & $0.275^{* *}$ & $0.231^{* *}$ & $0.188^{* * 4}$ & 0.105 & $0.310^{* *}$ & 0.072 & $x$ & & & & & \\
\hline Self-eff 8 & 0.086 & 0.019 & $0.245^{* *}$ & \begin{tabular}{|l|}
$0.211^{* *}$ \\
\end{tabular} & -0.084 & $0.234^{* *}$ & 0.073 & $\mathrm{x}$ & & & & \\
\hline Self-eff 9 & 0.085 & 0.044 & $0.350^{\text {*中 }}$ & $0.247^{* *}$ & 0.041 & $0.331^{* *}$ & $0.149^{* *}$ & $0.318^{* * *}$ & $\mathrm{x}$ & & & \\
\hline Self-eff 10 & $0.274^{* *}$ & $0.222^{* *}$ & 0.027 & $0.116^{*}$ & \begin{tabular}{|l|}
$0.237^{* *}$ \\
\end{tabular} & 0.078 & $0.301^{* *}$ & 0.017 & $0.121^{*}$ & $\mathrm{x}$ & & \\
\hline Self-eff 11 & $0.154^{* *}$ & $0.142^{* *}$ & $0.220^{* * *}$ & $0.383^{* *}$ & \begin{tabular}{|l|l|}
$0.181^{* *}$ \\
\end{tabular} & $0.212^{* *}$ & $0.150^{* *}$ & $0.302^{\text {** }}$ & $0.264^{* *}$ & $0.205^{* *}$ & $\mathrm{x}$ & \\
\hline Self-eff 12 & $0.163 * *$ & $0.139 *$ & $0.300^{* *}$ & $0.144^{* *}$ & $0.138^{* *}$ & $0.303^{* *}$ & $0.260^{* *}$ & $0.110^{*}$ & $0.353^{\text {\#* }}$ & $0.168^{\text {*** }}$ & $0.253^{* * *}$ & $\mathrm{x}$ \\
\hline
\end{tabular}

Note: Self-eff $=$ Self-efficacy

*Correlation was significant at the 0.05 level

** Correlation was significant at the 0.01 level

Table 2: The Pearson correlation between the 12 items of GSES

The Pearson revealed 49 significant relationships of below moderate strength. All of the relationships between the items of the 12-item GSES had positive directions, as shown in the table above. According to the aforementioned guidelines (Hinkle et al. 2003), there were no correlations of high and moderate strength between the 12 items of the GSES. Low correlations (0.30-0.49) were revealed in only 10 relationships, with the highest level of 0.383 between items 11 (I do not start learning new things if I think they are too difficult) and item 4 (If I have the impression something new is complicated, I do not start it). Thus, the results of the correlation analysis of the 12 -item GSES indicated the suitability of this variable for statistical analysis in this study.

After preparing the correlation matrix, the study analysis proceeded to stage 3 - the factor analysis of the 12-item GSES. This stage identified the underlying structure of relationships within the GSES construct to partially address RQ1 (Sherer et al. 1982; Bosscher \& Smit, 1998).

In addressing RQ1: 'Is there any association between accounting near-graduate students' individual characteristics and self-efficacy components of GSES?' a factor analysis, the Mann-Whitney U test and the chi-square tests were undertaken.

The study used the KMO measure of sampling adequacy (Kaiser, 1974). The KMO statistics can vary between 0 and 1 , where a value of $\mathrm{KMO}$ close to 0 indicates that the sum of partial correlations is 
INTERNATIONAL JOURNAL OF ACADEMIC RESEARCH IN BUSINESS AND SOCIAL SCIENCES Vol. 10, No. 2, Feb, 2020, E-ISSN: 2222-6990 @ 2020 HRMARS

large relative to the sum of correlations. This indicates diffusion in the pattern of correlation and if this was the case, the factor analysis technique would not be appropriate. A value of KMO close to 1 indicates that the patterns of correlations are more compact; in such cases the factor analysis would be applicable to produce distinct and reliable factors (Kaiser, 1974). According to Kaiser, KMO levels of 0.00 to 0.49 are unacceptable; 0.50 to 0.59 miserable; 0.60 to 0.69 mediocre; 0.70 to 0.79 middling; 0.80 to 0.89 meritorious; and 0.90 to 1.00 marvellous, as the greater the value of KMO, the better the reliability of the factor analysis technique. The KMO value of 0.776 obtained for the 12 -item GSES variable meant that the assumption for adequacy of factor analysis technique in this study was satisfied.

The appropriateness of the factor analysis for the study sample was further checked by using Bartlett's test of sphericity. This test indicates statistical significance in cases where the correlation matrix reveals significant correlations among at least some of the variables; it assumes factorability when the statistic is large and significant (Hair et al. 2010).

\begin{tabular}{|l|l|}
\hline & Value \\
\hline KMO measure of sampling adequacy & 0.776 \\
\hline $\begin{array}{l}\text { Bartlett's test of sphericity } \\
\text { Approximate chi-square }\end{array}$ & 591.305 \\
\hline $\mathrm{df}$ & 66 \\
\hline Significance (p-value) & 0.000 \\
\hline
\end{tabular}

Table 3: KMO and Bartlett tests - GSES

Bartlett's test of sphericity showed an approximate chi-square of 591.305, a degree of freedom of 66 and a significance value of 0.000 for all cases. This indicated that the GSES was adequate for a factor analysis.

The scale was also examined to reflect on its consistency and reliability. The reliability analysis was carried out on the full GSES and separately on the scale's three constructs by employing Cronbach's alpha. Cronbach's alpha measures reliability of a scale by splitting sample data into two in every possible way and by computing the correlation coefficient for every split of data. For a reliable scale the correlation coefficient should be large, the minimum acceptable level is above 0.5 . The results are presented in Table 4 below. 
INTERNATIONAL JOURNAL OF ACADEMIC RESEARCH IN BUSINESS AND SOCIAL SCIENCES Vol. 10, No. 2, Feb, 2020, E-ISSN: 2222-6990 @ 2020 HRMARS

\begin{tabular}{|l|l|l|l|l|l|}
\hline \multirow{2}{*}{ Sub (scale) } & \multirow{3}{*}{$\begin{array}{l}\text { Bosscher } \\
\text { and Smit }\end{array}$} & $\begin{array}{l}\text { Study sample data } \\
\mathrm{N}=337\end{array}$ & \multicolumn{2}{l|}{$\begin{array}{l}\text { Inter-item } \\
\text { min-max }\end{array}$} \\
\cline { 3 - 6 } & $\begin{array}{l}\text { Cronbach's } \\
\text { alpha }\end{array}$ & Standardised & $\begin{array}{l}\text { Bosscher } \\
\text { and Smit }\end{array}$ & $\begin{array}{l}\text { Study } \\
\text { sample data } \\
\mathrm{N}=337\end{array}$ \\
\hline GSES-12 & 0.69 & 0.720 & 0.723 & $0.04-0.45$ & $0.017-0.383$ \\
\hline Initiative & 0.64 & 0.553 & 0.561 & $0.30-0.45$ & $0.211-0.383$ \\
\hline Effort & 0.63 & 0.648 & 0.650 & $0.16-0.33$ & $0.215-0.329$ \\
\hline Persistence & 0.64 & 0.633 & 0.632 & $0.23-0.39$ & $0.164-0.353$ \\
\hline
\end{tabular}

Table 4: Comparison of Cronbach's alpha

The reliability for the 12 -item GSES used in this study $(n=337)$ shows slightly higher results $(0.720$ vs 0.69) compared to Bosscher and Smit's study. Inter-item correlations within 0.2 to 0.7 are normally acceptable and, as shown in the table, inter-item correlations were below the upper limit of the proposed threshold. When analysing each item separately on its effect on Cronbach's alpha, and considering the option of 'if item deleted', it was apparent that no removal of any item was required from the scale, so the reliability of the scale was justified. While the Cronbach's alpha for components effort and persistence were reasonably close (0.648 vs 0.63 and 0.633 vs 0.64 respectively), the initiative component of the scale resulted in a lower loading ( $0.553 \mathrm{vs} 0.64)$ for the full data set of this research.

\section{Determining the Number of Factors}

The study proceeded with the PCA technique as the dimension reducing method to identify the linear components of the 12-item GSES. The factor analysis was performed by using the method of extracting factors via CFA, to identify the underlying structure of relationships in the GSES items. According to Hair et al. (2010), the common variance in a variable is shared by all other variables in the analysis; the variable's communality, therefore, is the estimate of its shared variance.

As presented in Table 5 below, the communalities of the 12 items of the GSES, obtained by the extraction method of PCA, indicate that item number 10 had the lowest communality (0.379), followed by item $2(0.383)$ and item $3(0.386)$. The highest communality is indicated for item 12 (0.613), followed by items 4 (0.588), 9 and 11 (both of 0.569$)$. The results signify above moderate relationships (Pallant 2013) between the multivariate items of GSES. 
INTERNATIONAL JOURNAL OF ACADEMIC RESEARCH IN BUSINESS AND SOCIAL SCIENCES Vol. 10, No. 2, Feb, 2020, E-ISSN: 2222-6990 @ 2020 HRMARS

\begin{tabular}{|l|l|l|}
\hline $\begin{array}{l}\text { Item in } \\
\text { the GSES }\end{array}$ & Statement in the GSES & Extraction \\
\hline 1 & $\begin{array}{l}\text { If I make plans, I am convinced I will succeed in executing } \\
\text { them }\end{array}$ & 0.455 \\
\hline 2 & $\begin{array}{l}\text { If I have a failure the first time, I bite into it until it is going } \\
\text { better }\end{array}$ & 0.383 \\
\hline 3 & If I absolutely want something, it usually goes wrong & 0.386 \\
\hline 4 & $\begin{array}{l}\text { If I have the impression something new is complicated, I do } \\
\text { not start it }\end{array}$ & 0.588 \\
\hline 5 & $\begin{array}{l}\text { Even with unpleasant tasks I hold on until I am finished } \\
\text { I have difficulties solving problems well in my life }\end{array}$ & 0.458 \\
\hline 6 & If I have made a decision to do something, I will do it & 0.393 \\
\hline 8 & $\begin{array}{l}\text { If I start something new, I soon have to have the idea I'm on } \\
\text { the right track, otherwise I quit }\end{array}$ & 0.478 \\
\hline 9 & Unexpected problems make me quickly lose my balance & 0.569 \\
\hline 10 & If I make a mistake, I try even harder & 0.379 \\
\hline 11 & $\begin{array}{l}\text { I do not start learning new things if I think they are too } \\
\text { difficult }\end{array}$ & 0.569 \\
\hline 12 & I doubt myself & 0.613 \\
\hline
\end{tabular}

Table 5. Communalities of the 12-item GSES

The following figure shows the eigenvalue results obtained from PCA.

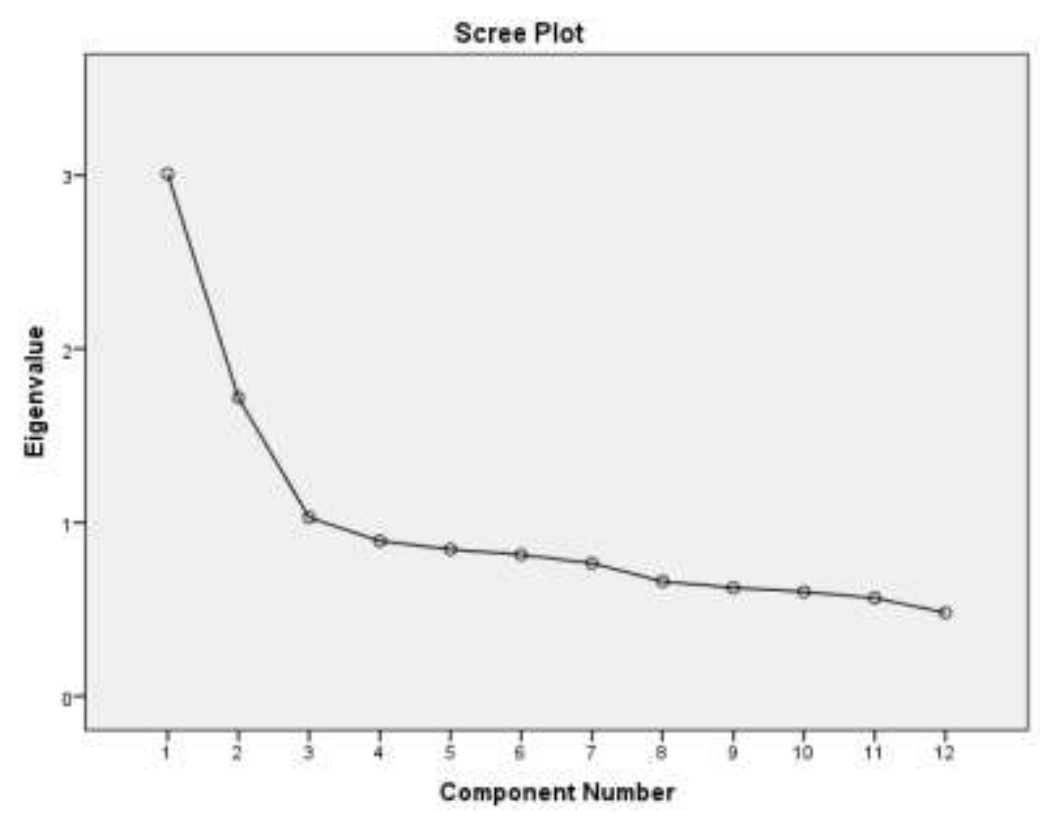

Figure 4: Eigenvalue of GSES

As shown in Figure 4 above, even without any rotation, the factor analysis showed three factors extracted with an eigenvalue greater than one. The extraction sum of square loadings for component 
INTERNATIONAL JOURNAL OF ACADEMIC RESEARCH IN BUSINESS AND SOCIAL SCIENCES Vol. 10, No. 2, Feb, 2020, E-ISSN: 2222-6990 @ 2020 HRMARS

1 was 3.006, for component 2 was 1.717 and for component 3 was 1.029 . The percentages of the variance for the three factors were indicated with the extraction sums of their squared loading (25.05 percent, 14.31 percent and 8.57 percent respectively for the three components). The cumulative percentage of variances of the three factors equalled 47.93 percent, indicating that if three factors were extracted then 47.93 percent of the GSES variance would be explained.

The factor matrix with the PCA extraction method showed three groups of factors with the included items within them. The factor matrix also revealed the correlations between the three factors of the GSES variable; however, each of the 12 items of the GSES had cross loadings between the factors. Since the data included a large number of variables, significantly correlated with each other, the oblique rotation should, in theory, provide more accurate results (Field 2009). Hence, the study employed the oblique rotation of the 12-item GSES.

\section{Oblique rotation}

The oblique rotation produced two matrices: the pattern matrix and the structure matrix. The rotation converged in seven iterations and resulted in a different structure, which provides a solution by assigning each of the 12 items of the GSES to only one of the three factors. Thus, the pattern matrix produced by direct oblique rotation with Kaiser normalisation revealed three factors comprising different items from the GSES.

Three factors' loadings

The identified factors persistence, effort and initiative were employed in the logistic regression analysis as separate independent variables. The structure matrix shown in Table 6 below was used to allocate each item of the GSES into the three factors: persistence (item 3, 6, 9, 12), effort (1, 2, 5, $7,10)$ and initiative $(4,8,11)$. The transformation of individual components of the 12 -item GSES into three new variables was performed via factor analysis (i.e., a PCA method). This method of transformation of variables was justified in the research, where the validity of scales was tested and confirmed (Wilson 2002).

\begin{tabular}{|l|l|l|}
\hline $\begin{array}{l}\text { Item in } \\
\text { the GSES }\end{array}$ & Statement in the GSES & Extraction \\
\hline 1 & If I make plans, I am convinced I will succeed in executing them & 0.455 \\
\hline 2 & If I have a failure the first time, I bite into it until it is going better & 0.383 \\
\hline 3 & If I absolutely want something, it usually goes wrong & 0.386 \\
\hline 4 & If I have the impression something new is complicated, I do not start it & 0.588 \\
\hline 5 & Even with unpleasant tasks I hold on until I am finished & 0.458 \\
\hline 6 & I have difficulties solving problems well in my life & 0.393 \\
\hline 7 & If I have made a decision to do something, I will do it & 0.481 \\
\hline 8 & $\begin{array}{l}\text { If I start something new, I soon have to have the idea I'm on the right } \\
\text { track, otherwise I quit }\end{array}$ & 0.478 \\
\hline 9 & Unexpected problems make me quickly lose my balance & 0.569 \\
\hline 10 & If I make a mistake, I try even harder & 0.379 \\
\hline 11 & I do not start learning new things if I think they are too difficult & 0.569 \\
\hline 12 & I doubt myself & 0.613 \\
\hline
\end{tabular}

Table 6: Structure matrix of the 12-item GSES

The three-factor structure of the GSES, identified through the analysis above, confirmed the findings of prior literature (Sherer et al. 1982; Bosscher \& Smit, 1998). 
INTERNATIONAL JOURNAL OF ACADEMIC RESEARCH IN BUSINESS AND SOCIAL SCIENCES Vol. 10, No. 2, Feb, 2020, E-ISSN: 2222-6990 @ 2020 HRMARS

Descriptive statistics of the three factors

The descriptive statistics of the three factors are highlighted in the following table.

\begin{tabular}{|l|l|l|l|}
\hline & Initiative & Effort & Persistence \\
\hline Mean & 3.4332 & 4.1941 & 3.4651 \\
\hline Median & 3.3333 & 4.2000 & 3.5000 \\
\hline Standard deviation & 0.8081 & 0.4773 & 0.7783 \\
\hline
\end{tabular}

Table 7. Descriptive statistics of the three factors

Table 7 shows that of the three factors, the highest mean was obtained for effort, which demonstrates that students in the study sample perceived the effort factor as more important than initiative and persistence. The results for the two other factors (initiative and persistence) are very similar (3.4332 for initiative and 3.4651 for persistence), which indicates that students in the sample data had similar expectations of their perceived initiative and persistence factors, associated with their self-esteem (Sherer et al. 1982).

Correlations between the three factors

Further analysis of correlations between the three identified factors (initiative, effort and persistence) were carried out and are presented in Table 8 below.

\begin{tabular}{|l|l|l|l|}
\hline Three self-efficacy factors (n=337) & Initiative & Effort & Persistence \\
\hline Initiative & & & \\
Pearson correlation & 1 & & \\
Sig (2-tailed) & - & & \\
Sum of squares and cross-products & 219.414 & & \\
Covariance & 0.653 & & \\
\hline Effort & & & \\
Pearson correlation & 0.210 & 1 & \\
Sig (2-tailed) & 0.000 & - & \\
Sum of squares and cross-products & 27.266 & 76.548 & \\
Covariance & 0.081 & 0.228 & \\
\hline Persistence & & & \\
Pearson correlation & 0.440 & 0.244 & 1 \\
Sig (2-tailed) & 0.000 & 0.000 & - \\
Sum of squares and cross-products & 93.007 & 30.480 & 203.528 \\
Covariance & 0.277 & 0.091 & 0.606 \\
\hline
\end{tabular}

Table 8: Correlations between the three factors

The results shown in Table 8 above indicate that the correlations between the three factors of the GSES were significant but of different strengths. Low positive correlation was revealed between factors initiative and persistence (0.440), while little if any correlation was identified between initiative and effort (0.210) and effort and persistence (0.244). This supports the use of these three factors as separate variables for further analysis.

The three-factor construct of self-efficacy efficacy for accounting near-graduates and the loadings of appropriate items within each factor are presented in Table 9 below. 
INTERNATIONAL JOURNAL OF ACADEMIC RESEARCH IN BUSINESS AND SOCIAL SCIENCES Vol. 10, No. 2, Feb, 2020, E-ISSN: 2222-6990 @ 2020 HRMARS

\begin{tabular}{|c|c|c|c|}
\hline Items & Statements as per GSES & $\begin{array}{l}\text { Bosscher } \\
\text { and Smit } \\
\text { (1998) }\end{array}$ & $\begin{array}{l}\text { This study } \\
\text { samples } \\
(\mathrm{n}=337)\end{array}$ \\
\hline \multicolumn{4}{|c|}{ Initiative } \\
\hline 4 & $\begin{array}{l}\text { If I have the impression something new } \\
\text { is complicated, I do not start it }\end{array}$ & 0.740 & 0.755 \\
\hline 8 & $\begin{array}{l}\text { If I start something new, I soon have to } \\
\text { have the idea I'm on the right track, } \\
\text { otherwise I quit. }\end{array}$ & 0.600 & 0.632 \\
\hline 11 & $\begin{array}{l}\text { I do not start learning new things if I } \\
\text { think they are too difficult }\end{array}$ & 0.500 & 0.718 \\
\hline \multicolumn{4}{|l|}{ Effort } \\
\hline 1 & $\begin{array}{l}\text { If I make plans, I am convinced I will } \\
\text { succeed in executing them }\end{array}$ & 0.570 & 0.668 \\
\hline 2 & $\begin{array}{l}\text { If I have a failure the first time, I bite into } \\
\text { it until it is going better }\end{array}$ & 0.490 & 0.599 \\
\hline 5 & $\begin{array}{l}\text { Even with unpleasant tasks I hold on } \\
\text { until I am finished }\end{array}$ & 0.530 & 0.675 \\
\hline 7 & $\begin{array}{l}\text { If I have made a decision to do } \\
\text { something, I will do it. }\end{array}$ & 0.560 & 0.627 \\
\hline 10 & If I make a mistake, I try even harder & 0.410 & 0.613 \\
\hline \multicolumn{4}{|c|}{ Persistence } \\
\hline 3 & $\begin{array}{l}\text { If I absolutely want something, it usually } \\
\text { goes wrong }\end{array}$ & 0.370 & 0.596 \\
\hline 6 & $\begin{array}{l}\text { I have difficulties solving problems well } \\
\text { in my life }\end{array}$ & 0.610 & 0.622 \\
\hline 9 & $\begin{array}{l}\text { Unexpected problems make me quickly } \\
\text { lose my balance }\end{array}$ & 0.620 & 0.735 \\
\hline 12 & I doubt myself & 0.620 & 0.739 \\
\hline
\end{tabular}

Table 9: Comparison of factor loadings

The present study's factor components reveal a similar structure to previous findings, with the contents (i.e., items) of each of the three factors identical. However, the factor loadings between this study and prior studies were different. The highest difference in loading was shown for item 3 (in persistence, 0.596 and 0.370 ), followed by item 10 (in effort: 0.613 and 0.410 ), and item 11 (in initiative: 0.718 and 0.500$)$. Overall, the study sample indicated higher loadings in all items throughout the three factors. This suggests that, in the sample data of the current study, the items of self-efficacy had greater correlation in loadings of items compared to the sample in Bosscher and Smit (1998), as indicated by each item in the three factors: initiative, effort and persistence.

The results of the Mann-Whitney U-tests of association between student individual characteristics and self-efficacy factors are shown in Table 10. 
INTERNATIONAL JOURNAL OF ACADEMIC RESEARCH IN BUSINESS AND SOCIAL SCIENCES Vol. 10, No. 2, Feb, 2020, E-ISSN: 2222-6990 @ 2020 HRMARS

\begin{tabular}{|c|c|c|c|}
\hline \multirow[t]{2}{*}{$\begin{array}{l}\text { Groups separated } \\
\text { by: }\end{array}$} & \multicolumn{3}{|c|}{$\begin{array}{l}\text { Mann-Whitney U test } \\
\text { Asymptotic 2-tailed significance at confidence level of 95\% }\end{array}$} \\
\hline & Initiative & Effort & Persistence \\
\hline Gender & 0.498 & 0.355 & 0.373 \\
\hline Language & $0.000 * * *$ & 0.825 & 0.344 \\
\hline Residency & $0.000 * * *$ & 0.055 & $0.008 * * *$ \\
\hline Study mode & 0.767 & $0.011^{*}$ & $0.047^{*}$ \\
\hline
\end{tabular}

Table 10: Mann-Whitney U tests of association between students' self-efficacy factors and gender, language, residency and study mode

The Mann-Whitney $U$ test was conducted at the $5 \%$ level of significance. The results revealed that a student's degree of self-efficacy is significantly associated with certain individual characteristics. The results in Table 10 indicate that while gender did not show significance in any of the three self-efficacy factors, a significant association was revealed for two self-efficacy factors (effort $\mathrm{p}=0.011$ and persistence $\mathrm{p}=0.047$ ) based on students' study mode, with part-time students exhibiting greater perceived self-efficacy in these two components compared to full-time students. This is supported by their mean ranks (see Appendix E). With respect to students' residency, two self-efficacy factors (initiative $p=0.000$ and persistence $p=0.008$ ) were significantly associated and the mean ranks showed the higher values in all three components for international students compared to domestic students (see Appendix E). In addition, the factor initiative showed significance $(p=0.000)$ for students of different language backgrounds, specifically that students from an English-speaking background (ESB) had higher perceived levels of initiative.

With respect to the variable age, this study employed a Pearson chi-square test. The results of the analysis are presented in Table 11 below.

\begin{tabular}{|l|l|l|l|}
\hline & Initiative & Effort & Persistence \\
\hline Pearson chi-square value & 21.423 & 23.832 & 47.368 \\
\hline Significance (2-sided) & 0.974 & 0.972 & 0.376 \\
\hline Likelihood ratio & 22.670 & 26.237 & 44.424 \\
\hline Significance (2-sided) & 0.959 & 0.941 & 0.496 \\
\hline Symmetric measures: & & & \\
\hline Pearson's r value approx. & 0.500 & 0.092 & 0.027 \\
\hline $\begin{array}{l}\text { Pearson's r (based on } \\
\text { significance } \\
\text { normal approximation) }\end{array}$ & 0.093 & 0.627 \\
\hline
\end{tabular}

Table 11. Pearson chi-square test of association between students' self-efficacy factors and students' age

\footnotetext{
${ }^{2}$ The statistical significance testing standards for Mann-Whitney U tests of association are based on the 'three-star system' of symbolic codes used in social science research (Leahey 2005).
} 
INTERNATIONAL JOURNAL OF ACADEMIC RESEARCH IN BUSINESS AND SOCIAL SCIENCES Vol. 10, No. 2, Feb, 2020, E-ISSN: 2222-6990 @ 2020 HRMARS

Table 11above illustrates that there was no association with the three factors of self-efficacy (initiative $(p=0.974)$; effort $(p=0.972)$; and persistence $(p=0.376)$ ) and different age cohorts.

The above two tests (the Mann-Whitney $U$ test and Pearson chi-square test) were used to analyze the association between the self-efficacy factors and various student individual characteristics.

Self-efficacy factors and study mode

The test of association for the variable study mode revealed significant association with two factors of perceived self-efficacy: effort $(p=0.011)$ and persistence $(p=0.047)$. The present study suggests that part-time students are more confident and more determined to succeed compared to full-time students. These results support those of previous literature, where the impact of study mode on accounting students' self-efficacy was analysed (Jackson, 2013; Alzgool, 2019; Muhammad, Saoula, Issa \& Ahmed, 2019). In this study sample, the percentage of part-time students who secured employment was $37.5 \%$ ( 9 out of 24 students who studied in part-time mode), compared to $14.6 \%$ (45 out of 308) for full-time students. Thus, it was expected that students in part-time study mode possessed a higher level of self-efficacy due to exposure to the work environment. Furthermore, students who have work experience are seen as better equipped for challenges in their day to day life (Purdie et al. 2013), as they develop greater confidence resulting in stronger self-efficacy. The present study suggests that part-time students are more confident and more determined to succeed compared to full-time students. Thus, the study's findings are in accordance with prior research, as part-time students demonstrated greater levels of GSE in terms of effort and persistence.

Self-efficacy factors and residency

The study findings suggest that the international students' persistence, initiative and effort rank higher than those of domestic students. The study data analysis revealed that domestic and international students showed significant differences in relation to perceived levels of initiative $(p=0.000)$ and persistence $(p=0.008)$ and insignificant differences in effort $(p=0.055)$. Specifically, the results suggest that international students have higher levels in all three components of self-efficacy, as shown by their mean ranks. These findings support those of an Australian Government Educational Department (2014) research paper, which identified some of the difficulties and challenges for international students studying in Australia.

Self-efficacy factors and language

The present study suggests that students of ESB (English Speaking Background) and NESB (NonEnglish-Speaking Background) differ significantly in the initiative $(p=0.000)$ factor of self-efficacy (see Table 10). The mean ranks for ESB students were higher in initiative and persistence, but relatively similar in effort. The results of the current study support prior research, where the importance of language in students' self-efficacy and successful performance outcomes were emphasised (Jackson, 2013; James \& Otsuka, 2008; Freudenberg et al. 2010a; Khalid, Islam \& Ahmed, 2019).

Self-efficacy factors and gender

The Mann-Whitney $U$ test of association did not reveal any significant differences in either of the three factors: initiative $(p=0.498)$; effort $(p=0.355)$ and persistence $(p=0.373)$ based on gender differences in the sample data. However, the mean ranks revealed higher values in female students' initiative and effort, and lower in persistence.

When comparing the items within each factor, there are some differences revealed in students' perceptions of their initiative and persistence that potentially could be due to some female students feeling not as confident as their peers, being shy and perhaps influenced by different beliefs (e.g., 
INTERNATIONAL JOURNAL OF ACADEMIC RESEARCH IN BUSINESS AND SOCIAL SCIENCES Vol. 10, No. 2, Feb, 2020, E-ISSN: 2222-6990 @ 2020 HRMARS

international students). However, these differences appeared insignificant, as shown by the test of association results provided in Table 10, as the significance level of gender differences with selfefficacy factors initiative, effort and persistence was well above $\mathrm{p}=0.05$.

There was not much discrepancy in students' perceptions of their self-efficacy in terms of gender, as male and female students possess relatively similar self-efficacy factors.

Self-efficacy factors and age

Similar to gender, the variable age did not show significance in the test of association with selfefficacy factors, as initiative $(p=0.974)$, effort $(p=0.972)$ and persistence $(p=0.376)$ were above the accepted level of significance of $p=0.05$. Thus, no significant difference was found in the self-efficacy factors of the surveyed students separated by age groups. This suggests that, regardless of their age, the students in the sample data possessed relatively similar levels of initiative, effort and persistence. These findings support those of prior research.

\section{Summary on Self-efficacy}

This study addressed RQ1 by analysing the association between the students' individual characteristics and their self-efficacy factors. The study applied tests of association (using a MannWhitney $U$ test and Pearson chi-square test) between the three factors (initiative, effort and persistence) and the variables gender, age, language, residency and study mode, to reveal any significant associations between students' characteristics and those three self-efficacy factors.

Significant associations were revealed between students' individual characteristics, such as language, residency and study mode, and their self-efficacy. Part-time students showed significantly higher levels of self-efficacy in all three factors (initiative, effort and persistence) compared to full-time students. NESB students had significantly lower levels of initiative compared to ESB students, while significant differences for the initiative and persistence factors were identified between domestic and international students, with the latter experiencing higher mean rank levels. The present study however did not find any significant difference in perceived self-efficacy based on gender or age.

\section{Contribution of the Study}

The study contributes to accounting education research by analysing GSE as a three-factor construct rather than a composite self-efficacy variable. This has not been used previously in the accounting educational context. The three-factor construct enables an analysis of each factor specifically and independently of each other. This process provides a more in-depth analysis of self-efficacy when addressing accounting near-graduate students' employment outcomes, as well as WIL participation. Furthermore, there are no studies that have analysed the employment outcomes of accounting students as they approach graduation. This is an important consideration since, as Little (2003) indicated, employment problems are associated more with transition into the labour market than with longer term issues.

The results of this study provide some important implications for various stakeholders in relation to improving near-graduate accounting students' employment prospects. The study's recommendations are based on research findings, which indicate the significance of WIL participation; the self-efficacy factors of initiative and persistence; and students' individual characteristics: residency, age, and language and study mode. The implications of these findings are discussed below. 
INTERNATIONAL JOURNAL OF ACADEMIC RESEARCH IN BUSINESS AND SOCIAL SCIENCES

Vol. 10, No. 2, Feb, 2020, E-ISSN: 2222-6990 @ 2020 HRMARS

\section{References}

Alzgool, M. (2019). Nexus between Green HRM and Green Management towards Fostering Green Values. Management Science Letters, 9(12), 2073-2082.

Bandura, A. (1977). Self-efficacy: Towards a unified theory of behavioural change. Psychological Review, 84(2), 191-215.

Bandura, A. (1982). Self-efficacy mechanism in human agency. American Psychologist, 37(2), 122147.

Bandura, A. (1986). Social foundations of thought and action: A social cognitive theory. Englewood Cliffs, New Jersey: Prentice Hall.

Bandura, A. (1997). Self-efficacy: The exercise of control. W H Freeman/Times Books/ Henry Holt \& Co.

Bosscher, R., \& Smit, J. (1998). Confirmatory factor analysis of the general self-efficacy scale. Behaviour Research and Therapy, 36(3), 339-343.

Chen, G., Gully, S. M., \& Eden, D. (2001). Validation of a new general self-efficacy scale. Organisational Research Methods, January 2001, 4(1), 62-80.

Coakes, S. J. (2013). SPSS version 20.0 for Windows. Analysis without anguish. New York: Wiley.

Collis, J., \& Hussey, R., (2009). Business Research. A practical guide for undergraduate and postgraduate students (3rd ed.). New York: Palgrave, McMillan.

Comrey, Al., \& Lee, H. B. (1992). A first course in factor analysis (2nd ed.). New Jersey: Erlbaum, Hillsdale.

DeCoster, J., (1998). Overview of factor analysis, accessed 21 August 2015, http://www.stathelp.com/notes.html

Demagalhaes, R., Wilde, H., \& Fitzgerald, L. (2011). Factors affecting accounting students' employment choices: A comparison of students' and practitioners' views. Journal of Higher Education Theory and Practice, 11(2), 32-40.

Field, A. (2009). Discovering statistics using SPSS (3rd ed.). California: Sage.

Freudenberg, B., Brimble, M., \& Cameron, C. (2010). Where there is a WIL there is a way. Higher Education Research and Development, 29(5), 575-588.

Freudenberg, B., Brimble, M., Cameron, C., \& English, D. (2010). Professional accounting education The WIL experience. Journal of Cooperative Education and Internship, 45(1), 80-92.

Gardner, D. J., \& Peirce, J. L. (1998). Self-esteem and self-efficacy within the organisational context. Group and Organisational Management, 23(1), 48-70.

George, D., \& Mallery, P. (2010), SPSS for windows step by step: A simple guide and reference 17.0 (10th ed.). Boston: Pearson.

Guadagnoli, E., \& Velicer, W. F. (1988). Relation of sample size to the stability of component patterns. Psychological Bulletin, 103(2), 265-275.

Guan, Y., Deng, H., Sun, J., Wang, Y., Cai, Z., Ye, L., Fu, R., Wang, Y., Zhang, Y., Zhang, S., \& Li, Y. (2013). Career adaptability, job search self-efficacy and outcomes: A three- wave investigation among Chinese university graduates. Journal of Vocational Behaviour, 83(12), 561-570.

Hair, J. F., Black, W. C., Babin, B. J., Anderson, R. E., \& Tatham, R. L. (2006). Multivariate data analysis (6th ed.). Melbourne: Pearson Prentice Hall.

Hair, J.F., Black, W. C., Babin, B. J., \& Anderson, R. E. (2010). Multivariate data analysis (7th ed.). Melbourne: Pearson. New International Edition. 
INTERNATIONAL JOURNAL OF ACADEMIC RESEARCH IN BUSINESS AND SOCIAL SCIENCES

Vol. 10, No. 2, Feb, 2020, E-ISSN: 2222-6990 @ 2020 HRMARS

Hinkle, D.E., Wiersma, W., \& Jurs, S. (2003). Applied Statistics for the Behavioural Sciences (5 ${ }^{\text {th }}$ ed.). London: Hi Marketing.

Hinton, P. (2004). Statistics explained. A guide for social science students (2nd ed.). London: Taylor and Francis.

Hosmer, D. W., \& Lemeshow, S. (2000). Applied logistic regression (2nd ed.). New York: John Wiley and Sons, Inc.

https://internationaleducation.gov.au/research/researchpapers/Documents/Study\%20Pathways\%2 02014.

Jackson, D. (2013). The contribution of work-integrated learning to undergraduate employability skills outcomes. Asia-Pacific Journal of Cooperative Education, 14(2), 99-115.

Jackson, D. (2014). Testing a model of undergraduate competence in employability skills and its implications for stakeholders. Journal of Education and Work, 27(2), 220-242.

James, K., \& Otsuka, S. (2008). Racial biases in recruitment by accounting firms: The case of international Chinese applicants in Australia. Critical Perspectives on Accounting, 20(4), 469491.

Kaiser, H. (1974). An index of factorial simplicity. Psychometrica, 39(1), 31-35.

Khalid, N., Islam, D. M. Z., \& Ahmed, M. R. M. (2019). Sentrepreneurial Training and Organizational Performance: Implications for Future. Humanities \& Social Sciences Reviews, 7(2), 590-593.

Knight, P., \& Yorke, M. (2004). Learning, curriculum and employability in higher education, London: Routledge Falmer.

McDowall, T., Jackling, B., \& Natoli, R. (2015). Relationships between vocational interests and learning approaches to advance the quality of student learning in accounting. Accounting Education: An International Journal, 24(6), 498-513.

Muhammad, K., Saoula, O., Issa, M., \& Ahmed, U. (2019). Contract Management and Performance Characteristics: An Empirical and Managerial Implication for Indonesia. Management Science Letters, 9(8), 1289-1298.

Pallant, J. (2013). SPSS survival manual, (5th ed.). Sydney: Allen and Unwin.

Phillips, B. (2015). Fundamentals of SPSS. ACSPRI Summer Program in Research Methods and Research Technology, University of Melbourne, 9-13 February 2015.

Purdie, F., Ward, L., Mcadie, T., \& King, N. (2013). Are work-integrated learning (WIL) students better equipped psychologically for work post-graduation than their non-work-integrated learning peers? Some initial findings from a UK university. Asia Pacific Journal of Cooperative Education, 14(2), 117-125.

Rothwell, A., Herbert, I., \& Rothwell, F. (2008). Self-perceived employability: Construction and initial validation of a scale for university students. Journal of Vocational Behaviour, 73(1), 1-12.

Sackett, P. R., \& Larson, J, R., (1990). Research strategies and tactics in industrial and organizational psychology. In M. D., Dunnette, \& L. M. Hough (eds.), Handbook of industrial and organizational psychology, (2nd ed.), vol. 1, 419-489. Palo Alto, California: Consulting Psychologists Press.

Scandura A., Wiliiams, E. (2000). Research Methodology in Managements, current practises, trends and implications for future research. Academy of Managements Journals, 43(8), 1248-1284.

Sherer, M., Maddux, J., Mercandante, B., Prentice-Dunn, S., Jacobs, B., \& Rogers, R. (1982). The selfefficacy scale: Construction and validation. Psychological Reports, 51(2), 663-671. 
INTERNATIONAL JOURNAL OF ACADEMIC RESEARCH IN BUSINESS AND SOCIAL SCIENCES

Vol. 10, No. 2, Feb, 2020, E-ISSN: 2222-6990 @ 2020 HRMARS

Smith, C. (2012). Evaluating the quality of work-integrated learning curricula: A comprehensive framework. Higher Education Research and Development, 31(2), 247-262.

Smith, H. M., \& Betz, N. E. (2000). Development and validation of a scale of perceived social selfefficacy. Journal of Career Assessment, 8(3), 283-301.

Spearman, C. (1904) General intelligence, objectively determined and measured. American Journal of Psychology, 15(2), 201-293.

Study pathways of international students in Australia. (2015). Retrieved from

Thompson, B. (2004). Exploratory and confirmatory factor analysis: Understanding concepts and applications, Washington, DC: American Psychological Association, accessed 12 November 2015, http://dx.doi.org/10.1037/10694-001.

Tibshirani, R. (1996). Regression shrinkage and selection via the Lasso. Journal of the Royal Statistical Society. Series B (Methodological), 58(1), 267-288.

Tymon, A. (2011). The student perspective on employability. Studies in Higher Education, 38(6), 841856.

Wilson, R. M. S. (2002). Accounting education research: a retrospective over ten years with some pointers to the future. Accounting Education: An International Journal, 11(4), 295-310.

Wood, R., \& Bandura, A. (1989). Social cognitive theory of organisational management. Academy of Management Review, 14(3), 361-384. 